UDC 130.122:37.013

DOI: https://doi.org/10.30839/2072-7941.2018.149671

\title{
CONCEPT OF MANAGEMENT EDUCATION OF INFORMATIONAL SOCIETY
}

\author{
(C) KONONETS, M.O. \\ National Technical University of Ukraine Igor Sikorsky Kyiv Polytechnic Institute, \\ (Kyiv, Ukraine) \\ E-mail: kononets.maria@gmail.com, ORCID 0000-0001-9303-707X
}

\begin{abstract}
Relevance of the research topic is that management education as a complex social phenomenon of the present, is an integral part of the formation of managerial culture of the head. Management education is interpreted from different sides, which suggests that managerial education is an interdisciplinary matrix of many socio-humanities and behavioral sciences. Problem statement - managerial education helps to form the personal qualities of the manager, which in general contributes to the formation of the concept of personal management. It is at the post-industrial stage that the formation and development of managerial education, based on knowledge, intellect, and professionalism, takes place. The analysis of recent researches and publications - for analysis, we highlight the publications of V.Beh, Yu.Beh, V.Voronkova, O.Kivlyuk, V.Nikitenko, M.Maksmenyuk, R.Olexenko, O.Punchchenko, O.Sosnin, which allow us to penetrate into the essence of management culture as the basis of managerial education. The selection of unexplored parts of the general problem - management culture as a complex social phenomenon remains rather insufficiently analyzed, all transformations in our country depend on its level and high quality. Problem statement - analysis of the methodological principles of managerial education in the context of the philosophy of education. Methods - general science and methods of constructive methodology applied to management sciences. In the economic, sociological, sociophilosophical literature of recent years the concept of "learning society" has become widespread. Main material presenting. At the core of the study - the conceptualization of methodological principles that allow to penetrate into such a complex phenomenon as managerial science, updated in the era of the information society, the development of directions for improving teaching management science in the transition to a new technological structure.The scientific novelty of the research is the application of constructive methodology, which shows that management science is a science of praxeological orientation. It is proved that the most important attributes of managerial culture, aimed at analysis of a complex selfregulated system, are self-organization and reflexivity.They are those attributes that contribute to the formation of an innovative management paradigm. It qualitatively accelerates the process of development and transformation of society through the inclusion of intentional and unpredictable consequences in it. All these factors accelerate the transformational processes in modern Ukrainian society. Conclusions - the philosophy of education should be regarded as a process, result and social phenomenon. The main task of managerial sciences is the prognostic, which investigates the laws of objective reality, aimed at increasing the information, production and organizational potential. The use of this potential contributes to the formation of the concept of personal management of the manager, which is necessary to solve the problems of modern society and increase the dynamic development of the state and society.
\end{abstract}

Key words: managerial education, philosophy of education, personal management, managerial culture, innovative management paradigm, information society 
The problem presentation in general terms and its connection with important scientific or practical tasks

Relevance of the research topic is that management education as a complex social phenomenon of the present, is an integral part of the formation of managerial culture of the head. Management education is interpreted from different sides, which suggests that managerial education is an interdisciplinary matrix of many socio-humanities and behavioral sciences.

Problem statement - managerial education helps to form the personal qualities of the manager, which in general contributes to the formation of the concept of personal management. It is at the post-industrial stage that the formation and development of managerial education, based on knowledge, intellect, and professionalism, takes place.

The research is based on the conceptualization of methodological principles that allow penetrating such a complex phenomenon as a management culture that is updated in the era of the information society, the development of directions for improving the teaching of managerial sciences in the context of the transition to a new technological structure [1].

Management culture as a sphere of culture (all that is created by man) is characterized by the following features: 1) in contrast to the technology is ideal; 2) its purpose is the process of mastering the world through the development of true knowledge and the way of cultural creativity; 3) construction of various fragments of educational, cultural and scientific activities [2].

An analysis of recent research and publications, which initiated the solution of the problem

The analysis of recent researches and publications - for analysis, we highlight the publications of V. Beh, Yu.Beh, V.Voronkova, O.Kivlyuk, V.Nikitenko, M.Maksmenyuk, R.Olexenko, O.Punchchenko, O.Sosnin, which allow us to penetrate into the essence of management culture as the basis of managerial education.

The selection of unexplored parts of the general problem - management culture as a complex social phenomenon remains rather insufficiently analyzed, all transformations in our country depend on its level and high quality.

Problem statement - analysis of the methodological principles of managerial education in the context of the philosophy of education.

Methods - general science and methods of constructive methodology applied to management sciences. In the economic, sociological, sociophilosophical literature of recent years the concept of "learning society" has become widespread.

Identification of previously unsettled parts of the general problem to which the article is devoted. Problem situation.

Thanking the skillful management of complex hierarchical systems, threats and "global challenges" that go from the environment can be overcome self-reflexively, as they are able to recycle information critically.

Management culture, which manifests itself in the form of 
complex hierarchical systems and operates in conditions of uncertainty, information stochasticity, and "balancing on the verge of chaos" is due to self-organization and contributes to the cultural core of the system and management cycle.

As a result of these mechanisms, a system that manages its own surrounding world, ultimately owns and promotes its efficiency. It is this managerial culture of information society to be formed in the system of higher education of the XXI century [2].

The purpose of the research is the conceptualization of the management education of the information society.

This goal is realized in the following tasks:

- to reveal the essence of the managerial education, aimed at increasing the place and role of leader in modern societies;

- to determine the role of managerial education as a factor in the formation of managerial culture and identify its components;

- to find out the conceptualcategorical apparatus necessary for the conceptualization of managerial education as a complex social phenomenon and the dynamic process of informational society;

- to analyze the synergeticreflexive model of governance necessary to solve the problems of stochasticity, uncertainty and "balancing on the verge of chaos".

\section{Discussion of the problem}

The concept of the managerial culture of the information society is due to the socio-cultural and socioeconomic dynamics of society in the face of fundamentally new challenges of a global nature. This is also due to the growing vulnerability of the "society of risk", whose nature is extremely complex, as the bulk of the population lives in a "society of ignorance" [3].

Social vulnerability cannot be clearly limited in space and time, hence - the cultivation of new knowledge about a complex society, taking into account the social framework of vulnerability, which begins to complicate and requires new knowledge about management education and culture, requires new managerial thinking and theorizing.

The main reason for the analysis of the new problems of the complexity of the information society and the age of globalization is that managers should not be guided by positivist thinking, which reduces the role of value, communicative, humane, interdialogue relations, which is the basis of a new managerial culture, as well as a new approach to information society as a society of great complexity, the analysis of the nature of which requires new methodological techniques and approaches [4].

The solution to the crisis is impossible without solving the problems of a complex society, which is based on informational nature, moving on a new trajectory of development, focused on the production of humane social practices and technologies.

The solution to these problems is possible through the networking of representatives of social, natural and humanitarian sciences, redefinition of knowledge about man and for a 
person, aimed at modernization (transformation) of modern society.

The most important attributes of the end-secret of management culture, aimed at analyzing a complex selfregulating system, are selforganization and reflexivity.

This qualitatively accelerates the process of development and transformation of society by including it intentional and unpredictable consequences, all that accelerates the vulnerability of individuals in the complex society. However, the complexity of vulnerability does not mean that these processes cannot be influenced and managed by them. To do this, in a reflexive structure operating in an information society, a reflexive individual with a high management culture must act [5].

Socium has always evolved, but today we are dealing with a complex society and its rapid formation, which is based on "society in action", experiencing its associated social cultural trauma there as a result of destructive interactions [6].

Life activity in a complex society demanded a new social order of a new quality. Order and chaos is a certain state of balance in which the components have not disappeared completely in anarchy, but represent such a balance, representing a new view of the nature of social order, and the factors that make it. Still T.Parsons said that the theory of the functioning of social systems is a standard, the hierarchy of values and norms which penetrates into all levels of society, which involved mechanisms that in the case of certain deviations restore the social balance [7].
Now the situation is changing: with the complexity of society, efforts to restore social order are always generating further unpredictable consequences that push the society away from its orderly state (Urri). The social order in one country always depends on the complex ties with the ensuing transnational relations. Relationships between variables can be nonlinear, so one reason can lead to different consequences in different circumstances [8].

To minimize turbulence injuries is possible due to the managerial culture (managerial influence), due to the correspondence between the organization and the reflection and self-organization. In a complex society, the order is ensured by relatively small efforts of professional actors and at the expense of the general humanization of human relations, an increase in the creative and intellectual human capital.

The social dimension of the new complexity of the information society and the age of globalization are new rates of social change. We distinguish three factors of speed regarding the impact on the quality of society:

1) we have come to the limit of the actual human capabilities of the reflection of fast-moving events in order to make adequate decisions with humane goals and means;

2 ) in one society live people who exist in different temposlites (the effect of dyshronosus);

3 ) the influence of speed factors on social life, including technological changes related to the Internet, telecommunications, information and communication technologies [9]. 
The basis of the study of the managerial culture of the information society is the conceptualization of methodological foundations that allow to penetrate into such a complex phenomenon as managerial sciences, updated in the era of the information society, the development of directions for improving the teaching of management science in the transition to a new technological structure.

The scientific novelty of the research is the application of constructive methodology, which shows that management science is a science of praxeological orientation. It is proved that the most important attributes of managerial culture, aimed at analysis of a complex self-regulated system, are self-organization and reflexivity.

It is these attributes that contribute to the formation of an innovative management paradigm. It qualitatively accelerates the process of development and transformation of society through the inclusion of intentional and unpredictable consequences in it.

All this accelerates the transformational processes in modern Ukrainian society [9].

The scientific novelty of the research is the application of constructive methodology, which shows that management science is a science of praxeological orientation.

Conclusion - managerial education should be regarded as a process, result and social phenomenon. The main task of managerial sciences is the prognostic, which investigates the patterns of objective reality, aimed at increasing the information, production, organizational potential, necessary for solving the problems of modern society and increasing the dynamic development of the state and society [10].

Conclusions - the concept of managerial culture of the information society should be regarded as a process, result and social phenomenon. The main task of managerial sciences is the prognostic, which investigates the laws of objective reality, aimed at increasing the information, production, organizational potential.

The use of this potential contributes to the formation of the concept of personal management of the manager, which is necessary to solve the problems of modern society and increase the dynamic development of the state and society.

The concept of the management culture of the information society is a sphere of culture (all that is created by man), which is characterized by the following features:

1) in contrast to the technique is ideal;

2) its purpose is the process of mastering the world through the development of true knowledge and the way of cultural creativity;

3) construction of various fragments of educational, cultural and scientific activities, so it is important to know the forecasts of cultural policies for the future.

In addition, the concept of managerial culture of the information society is one of the key tasks of the state to ensure the effective functioning of both the sphere of production of material goods and services. 
One of the promising areas for Ukraine's development is the philosophy of education, which trains highly qualified specialists to work in a creative economy.

The main dimension of the managerial education's creativity is to identify its impact on entrepreneurship, generate and stimulate innovation, increase productivity and economic growth.

The concept of the management culture of the information society is the basis of smart, sustainable and comprehensive growth, global competitiveness, the creative industry, global technological revolution, the formation of future trends in technologies that are rapidly developing, reforming institutions for the transformation of our world in the context of building a sustainable development strategy for Ukrainian of society.

\section{REFERENCES}

1. Voronkova V.G. (2012). Formation of synergistically-reflexively model samoupravlìnskogo society: the civilizational context // Humanitarian Bulletin of Zaporizhzhшa State Engineering Academy / M-of education and science of Ukraine, Zaporizhzhia State Engineering Academy. Zaporizhzhia. Issue. 49. 17-28.

2. Kyvliuk, O. P. (2014). Modelling of information processes in the context of the information society. Gileâ. Issue 80. 222-226.

3. Kyvliuk, O. P. (2001). Features of the foundations of computer science in elementary school // computer in the school and family. Kiev: Institute of Pedagogics of Ukraine. Issue 5. 33-34.

4. Kyrychenko, M. O. (2017). Informatization as a factor of optimizing the ideology of the information society and ensuring its sustainable development. Scientific Journal «ScienceRise: Pedagogical Education». Issue 1 (9). 46-50.

5. Maksimenûk, M. Yu., Nikitenko, V. O. (2016). Informational and communicative society as a kind of complex social systems and interaction. Humanitarian Bulletin of Zaporizhzhya State Engineering Academy. Issue 66. 266-278.

6. Melnik, V.V. (2015). Aksìologičnij rotation of the modern philosophy of the culture as being the genesis of culture // Humanitarian Bulletin of Zaporizhzhwa State Engineering Academy / M-of education and science of Ukraine, Zaporizhzhia State Engineering Academy. Zaporizhzhia. Issue. 63. 208-217.

7. Nikitenko, Vitalina (2016). Conceptualization of geo-cultural values in the process of teaching of foreign language // Humanitarian Bulletin of Zaporizhzhia State Engineering Academy / M-of education and science of Ukraine, Zaporizhzhia State Engineering Academy. Zaporizhzhia. Issue. 64. 255-259.

8. Oleksenko, R.I.(2017). Features of formation of the philosophical values of creative entrepreneurs in the face of global challenges and trends of the development of the modern world. Melitopol: FOP Odnorog T. 228 s . ISBN 978-617-7566-09-9

9. Ryzhova, I.S. (2017). Smart-technology as a factor of development of modern design // Humanitarian Bulletin of Zaporizhzhia State Engineering Academy. Issue 69.174-183.

10. Ryzhova I.S., Prusak V.F., Migal S.P., Rezanova N.O. (2017). Design seredovisha: List-dovidnik/ed. d. filosof n., Prof. I.S. Ryzhovoï.Lviv: Space-M. 360. 
КОНОНЕЦЬ, М. О. - кандидат психологічних наук, доцент, доцент кафедри психології і педагогіки, Національний технічний університет України «Київський політехнічний інститут» (Київ, Україна)

E-mail: kononets.maria@gmail.com, ORCID: 0000-0001-9303-707X

\section{КОНЦЕПЦІЯ УПРАВЛІНСЬКОЇ ОСВІТИ ІНФОРМАЦІЙНОГО СУСПІЛЬСТВА}

Анотація. Актуальність теми дослідження в тому, що управлінська освіта як складний соціальний феномен сучасності, $є$ складовою частиною формування управлінської культури керівника. Управлінська освіта трактується 3 різних сторін, що свідчить, що управлінська освіта $\epsilon$ міждисциплінарною матрицею багатьох соціогуманітарних та поведінкових наук. Постановка проблеми - управлінська освіта допомагає формуванню персональних якостей керівника, що в цілому сприяє формуванню концепції персонального менеджменту. Саме на постіндустріальній стадії відбувається становлення i розвиток управлінської освіти, що базується на знаннях, інтелекті, професіоналізмі. Аналіз останніх досліджень і публікацій - для аналізу ми виділяємо публікації В.Беха, Ю.Бех, В.Воронкової, О.Кивлюк, В.Нікітенко, М.Максименюк, Р.Олексенка, О.Пунченка, О.Сосніна, що дозволяють нам проникнути в сутність управлінської культури як основи управлінської освіти. Виділення недосліджених частин загальної проблеми управлінська культура як складне соціальне явище залишається досить мало проаналізованою, від іiі рівня та високої якості залежать всі перетворення в нашій країні. Постановка завдання - аналіз методологічних засад управлінської освіти в контексті філософії освіти. Методи загальнонаукові та методи конструктивної методології, що застосовуються до управлінських наук. В економічній, соціологічній, соціальнофілософській літературі останніх років отримала розповсюдження концепція «суспільства, що навчається». Виклад основного матеріалу. В основі дослідження - концептуалізація методологічних засад, що дозволяють проникнути у таке складне явище, як управлінські науки, що оновлюються в епоху інформаційного суспільства, розробка напрямів удосконалення викладання управлінських наук в умовах переходу до нового технологічного укладу. Наукова новизна дослідження - в застосуванні конструктивної методології, яка свідчить про те, що управлінські науки - це науки праксеологічної спрямованості. Доведено, що найважливіші атрибути управлінської культури, направленої на аналіз складної саморегульованої системи, - це самоорганізація та рефлексивність. Саме ці атрибути сприяють формуванню інноваційної управлінської парадигми. Це якісно прискорює процес розвитку i трансформації соціуму за рахунок включення в нього інтенціональних, так і непередбачуваних наслідків. Все це прискорює трансформаційні процеси в сучасному українському суспільстві. Висновки - філософію освіти слід 
розглядати як процес, результат i соціальне явище. Головна задача управлінських наук - прогностична, яка досліджує закономірності об'єктивної реальності, направленої на те, щоб нарощувати інформаційний, виробничий, організаційний потенціал. Використання даного потенціалу сприяє формуванню концепції персонального менеджменту керівника, який необхідний для вирішення проблем сучасного суспільства та підвищення динамічного розвитку держави i суспільства.

Ключові слова: управлінська освіта, філософія освіти, персональний менеджмент, управлінська культура, інноваційна управлінська парадигма, інформаційне суспільство

КОНОНЕЦ, М. А. - кандидат психологических наук, доцент, доцент кафедры психологии и педагогики, Национальный технический университет Украины «Киевский политехнический институт» (Киев, Украина)

E-mail: kononets.maria@gmail.com, ORCID: 0000-0001-9303-707X

\section{КОНЦЕПЦИЯ УПРАВЛЕНЧЕСКОГО ОБРАЗОВАНИЯ ИНФОРМАЦИОННОГО ОБЩЕСТВА}

Аннотация. Актуальность темы исследования в том, что управленческое образование как сложный социальный феномен современности, есть сложной частью формирования управленческой культуры руководителя.Управленческое образование определяется с разных сторон, что свидетельствует о том, что управленческое образование есть междисциплинарной матрицей многих социогуманитарных и поведенческих наук. Постановка проблемы управленческое образование помогает формированию персональных качеств руководителя, что в целом содействует фомированию концепции персонального менеджента. Именно на постиндустриальной стадии поисходит становление и развитие управленческого образования, которое базируется на знаниях, интеллекте, профессионализме. Анализ последних иссследовниий и публикаций - для анализа мы выделяем публикации В.Беха, Ю.Бех, В.Воронковой, О.Кивлюк, В.Никитенко, М.Максименюк, Р.Олексенко, О.Пунченко, О.Соснина, которые позволяют нам проникнуть в сущность управленческой культуры как основы управленческого образования. Выделение неисследованных частей общей проблемы управленческая культура как сложное социальное явление остается достаточно мало проанализированной, от ее уровня и высокого качества зависят все превращения в нашей стране. Постановка задания - анализ методологических основ управенческого образования в контексте философии образования. Методы - общенаучные и конструктивной методологии, которые применяются к анализу управленческих наук. В 
экономической, социологической, социально-философской литературе последних лет получила распространение концепция «общества, которое обучается». Изложение основного материала. В основе исследования концептуализация методологических оснований, которые позволяют проникнуть в такое сложное явление, как управленческие науки, которые обновляются в эпоху информационного общества, разработка направлений усовершенствования изложения управенческих наук в условиях перехода к новому технологическому укладу. Научная новизна - в применении конструктвиной методологии, которая свидетельствует о том, что управленческие науки - это науки праксеологической направленности. Доказано, что самые важные атрибуты управленческой культуры, направленной на анализ сложной саморегулированной системы, - это самоорганизация и рефлексивность. Именно эти атрибуты содействуют формированию инновационной управленческой пардигмы. Это качественно ускоряет процесс развития и трансформации социума за счет включения в него интенциональных, так и непредвиденных последствий. Все это ускоряет трансформационные поцессы в современном украинском обществе. Выводы - философию образования следует рассматривать как процесс, результат и социальное явление. Главная задача управенческих наук - прогностическая, которая исследует закономерности объективной реальности, направленной на то, чтобы увеличивать информационный, производственный, организационный потенциал. Использование данного потенциала содействует формированию концепции персонального менеджмента руководителя, который необходим для решения проблем современного социума и повышения динамического развития государства и общества.

Ключевые слова: управленческое образование, философия образования, персональный менеджмент, управленческая культура, инновационная управленческая парадигма, информационное общество

Стаття рекомендована до публікащії д.філософ.н., проф.Воронковою В.Г. (Запоріжжя, Украӥна)

Надійшла до редколегї: 17.10.2018

Прийнята до друку: 22.10.2018 